\title{
Relationship between Students' Perception toward the Teaching and Learning Methods of Mathematics' Lecturer and Their Achievement in Pre-University Studies
}

\author{
Nor Amalina Ahmad ${ }^{1}$, Farah Liyana Azizan ${ }^{1}$, Nur Fazliana Rahim ${ }^{1}$, Nor Hayati Jaya ${ }^{1}$, Norhunaini Mohd \\ Shaipullah $^{1} \&$ Emmerline Shelda Siaw ${ }^{1}$ \\ ${ }^{1}$ Centre for Pre University Studies, Universiti Malaysia Sarawak, Sarawak, Malaysia \\ Correspondence: Nor Amalina Ahmad, Centre for Pre University Studies, Universiti Malaysia Sarawak, 94300 \\ Kota Samarahan, Sarawak, Malaysia. Tel: 82-582-498. E-mail: anamalina@unimas.my
}

Received: May 17, 2017

doi:10.5539/ies.v10n11p129
Accepted: June 20, $2017 \quad$ Online Published: October 28, 2017

URL: https://doi.org/10.5539/ies.v10n11p129

\begin{abstract}
The academic performance of students is affected by many factors, including effectiveness in teaching, the subjects taught and the environment as well as the facilities provided. The purpose of this study is to determine the relationship between students' perceptions of the teaching and learning towards the lecturers with their achievements in Mathematics at the Centre for Pre University Studies. The study was a descriptive study in which a survey research design was adopted. A total of 841 students from the centre participated in the study. The data were collected through student's questionnaire. The questionnaires consisted of 26 questions. 5-Likert Scale questionnaires used in this study focused on the five categories of students' perceptions; teaching, evaluations, subjects, guidance and environment dimensions. The findings revealed that there is no significant correlation between the average scores of students' perceptions of teaching and learning towards the Mathematics lecturer with the average scores Mathematics achievement of the students. The study also revealed that there are no significant differences between the average scores of male and female students' perceptions of the effectiveness of teaching and learning of the Mathematics lecturer. The findings of this study show that the lecturer can improve their teaching skills and techniques that are appropriate to the students.
\end{abstract}

Keywords: achievement, effectiveness, perception

\section{Introduction}

Education has a significant role in the development of a country. The progress of a country is also symbolized by the level of education provided. For most countries, the main factor to be considered is the quality and effectiveness of teaching and learning. The learning process becomes more significant with the increase in the quality of teaching and learning through continuous improvement (Tang \& Lim, 2002).

The teaching process will have an impact on teaching and learning, but sometimes does not produce good lessons to a student. Not only that, Robiah (2000) also mentioned that improving the quality of teaching and learning is the key to the development of education in Malaysia today. Therefore, it is necessary to ensure the quality of the lecturers teaching the subjects are good. In a globalization era, the lecturer must have high skills to ensure teaching and learning can take place systematically and meet the needs of students. Therefore it is necessary for the universities to evaluate their own effectiveness in delivering educational services, in particular teaching and learning to the students as the Malaysian Education Act for Higher Institutions of Learning of 1996 devolved authority for the control the development, performance standards and financial accountability to the institutions (Jamaliah \& Zaidatol, 2004).

\section{Problem Statement}

The institutions of higher education should be more competitive, conforming to the government policy and aspiration of transforming our country into the regional world-class centre of excellence in education in parallel with the increasing enrolment of students in various disciplines. Students are of the main stakeholder of an institution of higher education who needs to be prioritized, considering their individual needs which have to be fulfilled and they have the own right to get the good and quality education from the university and it is the responsibility of the university to ensure the program offered is qualified and suitable for them. Despite the 
significance mentioned, there is still not much effort contributed in investigating the relationship between students' perceptions of the quality of teaching to student achievement (Guolla, 1999). A research needs to be conducted to observe the relationship between students' perceptions of learning Mathematics from a lecturer and the students' own achievement.

\section{Literature Review}

The quality of higher education has to be related to the practice of knowledge and learning experience obtained by the students. There are a few components contained in the teaching and learning processes that are the main factors determining the quality of teaching which is consists of the lecturer (motivation, competence, the technique of building rapport with the students), teaching tools (courses, syllabus, media, teaching methods), students (students' competence, relationship among students), and instructional implementation (explanation on lecture materials, task assignment, evaluation, as well as restraints in teaching) (Suarman et al., 2013). According to Marsh (1990), Toland and De Ayala (2005), Gursoy and Umbreit (2005), Oxford Brookes University (2005), there are nine components of the quality of teaching and learning, which are the 1) courses, 2) lecturers' motivation, 3) instructional design, 4) relationship among students, 5) relationship between the students and lecturers, 6) assignment, 7) lecturers' competence, 8) obstacles and constraints, and 9) evaluation.

Mathematics is one of the basic subjects that are important for further studies in any field to be ventured by the students. Mathematics is seen by society as the foundation of scientific technology knowledge that is vital in social economic development of nation (Justice et al., 2015). Correspondingly, quality of lecturers plays a huge role as they are very significant in shaping and guiding students.

The low quality of teaching and learning process among lecturers is often questioned and become a problem in the field of education (Koster, 2000). According to Ramsden (1991), characteristics of effective teaching and learning process is good in teaching, freedom in learning, clear goals, appropriate teaching workloads and quality of lecturers.

This clearly shows that the quality of lecturers is an important aspect in providing effective instruction to students. Furthermore, the learning process also correlated with students' perceptions of the subject that has been studied. Effective learning is not only dependent on the skills and competencies of lecturers, but also depends on the overall strategy (Wilson \& Lizzion, 1997).

In fact, effective teaching should be linked to the quality of the students and how the effectiveness of learning guides them toward a more effective learning (Kelly, 2002). Teaching is also said to be effective if the increase in students' achievement is consistent with the goal of teaching after a period of teaching (Stringer \& Irwing, 1998).

The effectiveness, quality of teaching and education are very important in ensuring the success of one's career. According to Gordon and Partingon (expressed in Rowley, 1996), the quality of education refers to the success of an institution providing educational environment where students achieve learning goals as well as an effective academic measurement.

The effectiveness of education at the tertiary level can be judged from various aspects. There are the lecturers' educational background and different teaching experiences. Besides, the validity and reliability of studies that correlate the level of Teaching and Learning process of lecturer against students' achievement is often questionable.

There are studies that deny the positive relationship between qualities of teaching to students' achievement. However, not much effort was made to investigate the students' perceptions of the quality of teaching to student achievement (Guolla, 1999). Therefore, this study should be conducted to assess the relationship between students' perceptions of learning Mathematics from a lecturer and the students' own achievement.

\section{Objectives}

The objectives of the study are as follows:

a) To determine the students' perceptions of teaching and learning of mathematics lecturers.

b) To identify the students' perceptions of teaching and learning mathematics' lecturer towards the student achievement.

c) To determine the students' perceptions difference between male and female students towards the teaching and learning of mathematics lecturers.

\section{Method}

The purpose of this study is to know students' level of perception towards teaching and learning from the Pre 
University Studies Mathematics lecturers, and how strong is this variable affecting their performance. 5-Likert Scale questionnaires were used in this study focusing on the five categories of students' perceptions; teaching and evaluations, subjects, and guidance and environment dimensions. Likert-type or frequency scales use fixed choice response formats and are designed to measure attitudes or opinions (Bowling, 1997; Burns \& Grove, 1997) as shown in Table 1. These ordinal scales were used to allow the students to express how much they agree or disagree with a particular statement. They were offered a choice of five responses; strongly disagree, disagree, not sure, agree, and strongly agree. Not sure indicates the neutral point where the respondent either agrees or disagrees. The questionnaires consist of 12 items on teaching and evaluation dimensions, 4 items on subject dimensions and 10 items on guidance and environment dimensions.

Table 1. Level of perception towards quality of teaching and learning (Azizah et al., 2011)

\begin{tabular}{ccc}
\hline Scale & Perception & Category \\
\hline $1.00-1.99$ & Very low & Weak \\
$2.00-2.99$ & Low & Moderate \\
$3.00-3.99$ & Moderate & Good \\
$4.00-5.00$ & High & Excellent \\
\hline
\end{tabular}

The questionnaires were asked to 841 pre university students taking Mathematics as their core subject. Distributed according to programs, 520 of them were Life Sciences (LS) students while 321 were Physical Sciences (PS) students. All the respondents can be distributed in percentage by $32.5 \%$ male and $67.5 \%$ female.

\section{Results}

\subsection{Correlation Analysis}

Correlation Analysis is used in order to determine the relationship between students' perceptions towards Mathematics teachers' teaching and learning with the students' achievement in Mathematics. The Correlation coefficient used to determine these two variables was Pearson Product Moment Correlation Coefficient. The values of Pearson lie between minus one and one. Minus one indicated that there were total negative correlations while positive one indicated total positive correlation. Positive correlation means that if one variable increases the other increases too. Meanwhile, negative correlation means that if one variable increases, then the other decreases. Last but not least, a zero value indicates that the two variables were not related at all.

In order to assess the relationship between them, male students' perceptions of the quality of teaching and learning of their Mathematics lecturers have been correlated with their achievement in Mathematics. In addition, female students' perceptions of the quality of teaching and learning of their Mathematics lecturers also have been correlated with their achievement in Mathematics.

\subsection{T-Test}

T-test is used to determine whether there are differences in the perception of the quality of teaching and learning of Mathematics lecturers between the male and female students.

The data analysis used is Statistical Package for the Social Science (SPSS) version 22. Two types of statistical analysis were used to analyze the data obtained. First, descriptive statistics were used to examine the frequency and percentage of the approval level of quality teaching and learning of their Mathematics lecturers. The mean level of agreement for each dimension of quality teaching and learning of their Mathematics lecturers was also examined.

Secondly, for statistical inference ,Moment Pearson correlation was used to analyze the data to find relationships between students' perceptions of the quality of teaching and learning of Mathematics lecturers with the students' achievement in Mathematics, determine the relationship between the perception of male students on the quality of teaching and learning of Mathematics by pre-university lecturers with their achievement in Mathematics and determine the relationship between the perception of female students on the quality of teaching and learning of Mathematics by pre-university lecturers with their achievement in Mathematics.

T-test analysis was used to find the difference in perception of the quality of pre-university lecturers' teaching and learning of Mathematics between boys and girls.

\subsection{Analysis of Students Perception towards Mathematics Lecturers' Teaching and Learning (T\&L)}

Students' level of perceptions towards teaching and learning (T \& L) among Mathematics lecturer was based on 
the views of pre-university students in West Malaysia. There are five dimensions of $\mathrm{T} \& \mathrm{~L}$ that has been studied, which are teaching, assessment, subject, guidance and also environment dimension. Respondents gave their feedback whether to give a positive or negative perception on their Mathematics lecturers' T \& $\mathrm{L}$ in the lecture through the results of a survey questionnaire. Table 2 shows the analysis of the students' level of perception for each dimension of Mathematics lecturer's T \& L.

Table 2. Level of perception towards mathematics lecturer's teaching and learning

\begin{tabular}{ccc}
\hline Dimensions & Mean & Standard Deviation $(S D)$ \\
\hline Teaching & 4.16 & 0.52 \\
Evaluation & 4.11 & 0.56 \\
Subject & 4.06 & 0.59 \\
Guidance & 4.21 & 0.56 \\
Environment & 4.23 & 0.54 \\
\hline
\end{tabular}

Based on this analysis, it was found that the mean score perception of all the $\mathrm{T} \& \mathrm{~L}$ dimensions has a mean above 4.00. This shows that the level of students' perception on all dimensions of the Mathematics lecturer's T \& $\mathrm{L}$ is very high, which is an excellent category as described in the methodology.

\subsection{Hypothesis Test Analysis}

Table 3 shows the correlation analysis between students' overall perception towards Mathematics lecturers' T \& $\mathrm{L}$ with their achievement in Mathematics.

Table 3. Correlation between mathematics teachers' teaching and learning with students' mathematics achievement

\begin{tabular}{lcc}
\hline & & Mathematics Achievement \\
\hline \multirow{4}{*}{ Teaching and Learning } & Pearson Correlation & -0.06 \\
& Sig. (2-sample) & 0.10 \\
& $\mathrm{~N}$ & 841 \\
\hline
\end{tabular}

Based on the analysis above, the data shows that the correlation between students' perception towards their Mathematics lecturers' teaching and learning with their achievement in Mathematics was a weak negative correlation. It was proven by the result of the correlation test analysis where the value of $r=-0.06$ and the value of $p=0.10$. Referring to the value of $p$, it shows that Mathematics lecturers' teaching and learning quality was above the significant level, 0.05 . Therefore, this means that the null hypothesis were accepted which is there is no significant relationship between the students' perception towards the Mathematics lecturers' teaching and learning with their achievement in Mathematics. So, it can be concluded that the students' perception towards their Mathematics lecturers' teaching and learning did not affect their achievement in Mathematics. Even though the value of mean for each dimension of teaching and learning shows that the students' perception was in good and excellent category, it does not mean that their Mathematics achievement also good.

Next, Table 4 below shows the correlation analysis between male students' perception towards Mathematics lecturers' teaching and learning with their Mathematics achievement.

Table 4. Correlation between male students' perception towards mathematics teachers' teaching and learning with students' achievement in mathematics

\begin{tabular}{lcc}
\hline & Mathematics Achievement \\
\hline & Pearson Correlation & -0.05 \\
Teaching and Learning (Male Students) & Sig. (2-sample) & 0.45 \\
& $\mathrm{~N}$ & 273 \\
\hline
\end{tabular}

Referring to the above data, it was found that the correlation between male students' perception towards Mathematics lecturers' teaching and learning with their Mathematics' achievement was a weak negative 
correlation, which is the value of $r=-0.05$ and the value of $p=0.45$, which is more than the significant level, 0.05. This means that male students' perception towards teaching and learning does not affect their achievement in Mathematics. Therefore, the null hypothesis was accepted which is there is no significant relationship between male students' perception towards the Mathematics lecturers' teaching and learning with their achievement in Mathematics.

Next, the correlation analysis between female students' perception towards the Mathematics lecturers' teaching and learning with their achievement in Mathematics was shown in Table 5 below.

Table 5. Correlation between female students' perception towards mathematics teachers' teaching and learning with students' mathematics achievement

\begin{tabular}{lcc}
\hline & Mathematics Achievement \\
\hline & Pearson Correlation & -0.05 \\
Teaching and Learning (Female Students) & Sig. (2-sample) & 0.25 \\
& $\mathrm{~N}$ & 568 \\
\hline
\end{tabular}

With reference to the analysis above, we can see that the correlation between female students' perception towards their Mathematics lecturers' teaching and learning with the achievement in Mathematics was a weak negative correlation with the value of $r=-0.05$ and the value of $p=0.25$. This means that the female students' perception towards teaching and learning did not affect their achievement in Mathematics. Therefore, the null hypothesis, showing no significant relationship between female students' perception towards the Mathematics lecturer' teaching and learning with their achievement in Mathematics, was accepted.

The research proceeded with the t-test analysis. Table 6 shows the result of t-test analysis for the purpose of identifying whether there is a significant difference between male and female students' perceptions towards the Mathematics lecturers' teaching and learning.

Table 6. Differences in the perception of mathematics teachers' teaching and learning

\begin{tabular}{lcccccc}
\hline & $\mathrm{N}$ & Mean & $S D$ & $t$ & $d f$ & Sig \\
\hline Teaching and Learning & & & & -2.00 & 839 & 0.05 \\
Male & 273 & 4.11 & 0.52 & & & \\
Female & 568 & 4.18 & 0.44 & & & \\
\hline
\end{tabular}

Referring to the above table, it was found that the value of mean for male and female students' perception towards the Mathematics lecturers' teaching and learning is 4.11 and 4.18 respectively. These mean shows a positive perception towards the Mathematics lecturers' teaching and learning. The T-test analysis result shows that there is no significant difference between male and female perceptions towards the Mathematics lecturers' teaching and learning. Therefore, the null hypothesis was also accepted. This indicates that the gender difference also does not affect their perception towards Mathematics lecturers' teaching and learning.

\section{Conclusion}

Based on all the results that had been discussed, we can conclude that the level of students' perception was in both good and excellent categories. The result shows that there is no significant relationship between students' perception towards the Mathematics lecturers' teaching and learning with their achievement in Mathematics. Not only that, the result also shows that there is no significant difference between male and female students' perception towards the Mathematics lecturers' teaching and learning.

\section{Acknowledgements}

This research is fully supported by Scholarship of teaching and learning grant (SoTLG), C03/SoTL1/1340/2016. The authors fully acknowledged University Malaysia Sarawak for the approved fund which makes this important research viable and effective.

\section{References}

Azizah, R, Hamidah, A. R., \& Roziana, S. (2011). The international students' perception towards the education quality. International Journal of Social Sciences and Humanity studies, 3(2). 
Bowling, A. (1997). Research Methods in Health: investigating health and health services. Buckingham: Open University Press. Retrieved from www.simplypsychology.org/likert-scale.html

Burns, N., \& Grove, S. K. (1997). The practice of nursing research conduct, critique, \& utilization. W.B. Saunders and Co., Philadelphia.

Guolla, M. (1999). Assessing the teaching quality to student satisfaction relationship: Applied customer satisfaction research in the classroom. Journal of Marketing Theory and Practice, Summer, 87-97. https://doi.org/10.1080/10696679.1999.11501843

Gursoy, D., \& Umbreit, W. T. (2005). Exploring students' evaluations of teaching effectiveness: what factors are important? Journal of Hospitality \& Tourism Research, 29(1), 91-109. https://doi.org/10.1177/1096348004268197

Jamaliah, A. H., \& Zaidatol, A. L. P. (2004). Students's perceptions of the quality of teaching and learning in business studies programs. Pertanika Journal of Social Sciences \& Humanities, 71-86.

Justice, E., Osei, K. A., \& Daniel, N. (2015). Factors influencing students' mathematics performance in some selected colleges of education in Ghana. International Journal of Education Learning and Development, $3(3), 68-74$.

Kelly, R. R. (2002). Students Teachers. Retrieved from http://www.rit.edu/ rkelly/html/03_ped/ped_stul.html

Koster, W. (2000). Pengaruh input sekolah terhadap output sekolah: Kajian di SLTP Jakarta. Jurnal Pendidikan dan Kebudayaan. No 025.

Marsh, H. W., \& Hocevar, D. (1990). The Multidimensionality of students' evaluation of teaching effectiveness: The generality of factor structures across academic discipline, instructor level, and course level. Retrieved from http://www.mcmaster.ca/stlhl/documents/student\%20Evaluation \%20of\%20 Teaching.pdf

Oxford Brookes Universiti. (2005). Student satisfaction survey. Centre for research and evaluation. Sheffield Hallam Universiti.

Ramsden, P. (1991). A performance indicator of teaching quality in higher education. Studies In Higher Education, 16(2), 129-150. https://doi.org/10.1080/03075079112331382944

Robiah, S. (2000). Inovasi kaedah pengajaran: Pengalaman di Universiti Kebangsaan Malaysia. Prosiding National Conference on Teaching and Learning in Higher Education.

Rowley, J. (1996). Measuring quality in higher education. Quality in Higher Education, 2(3), 237-255. https://doi.org/10.1080/1353832960020306

Stringer, M. \& Irwing, P. (1998). Student's evaluations of teaching effectiveness: A structural modeling approach. $\begin{array}{lllll}\text { British Journal of } & \text { Educational }\end{array}$ https://doi.org/10.1111/j.2044-8279.1998.tb01301.x

Suarman., Zahara, A., \& Ruhizan, M.Y. (2013). The quality of teaching and learning towards the satisfaction among the university students. Journal of Asian Social Science, 9(12). https://doi.org/10.5539/ass.v9n12p252

Tang, S. M., \& Lim, K. T. (2002). Hubungan Antara Kualiti Pengajaran dan Pembelajaran dengan Kepuasan Pelajar: Satu Tinjauan, 3(1).

Toland, M. D., \& De Ayala, R. J. (2005, April). Validity Studies: A Multilevel factor analysis of students' evaluations of teaching. Lincoln, Educational and Psychological Measurement, 65(2), 272-296. https://doi.org/10.1177/0013164404268667

Wilson, K., \& Lizzio, A. (1997). The development, validation and application of the course experience questionnaire. Studies in Higher Education, 22(1), 33-62. https://doi.org/10.1080/03075079712331381121

\section{Copyrights}

Copyright for this article is retained by the author(s), with first publication rights granted to the journal.

This is an open-access article distributed under the terms and conditions of the Creative Commons Attribution license (http://creativecommons.org/licenses/by/4.0/). 